\title{
The Impact of Consumer Interactions in Social Networking Sites on Brand Perception
}

\author{
Karla Barajas-Portas \\ Universidad Anahuac Mexico Norte, Estado de Mexico, Mexico
}

Correspondence should be addressed to: Karla Barajas-Portas; karla.barajas@anahuac.mx

Received date: 27 February 2015; Accepted date: 29 June 2015; Published date: 7 September 2015

Academic Editor: Oluwole Iyiola

Copyright (C) 2015. Karla Barajas-Portas . Distributed under Creative Commons CC-BY 4.0

\begin{abstract}
The aim of the present research is to explore the impact of the interaction on the brand perception using as base the Social Networking sites. We propose an extended model which provides relevant information of the evolution of brand perception, considering one of the most relevant processes for the human being: socialization as interaction through Social Media. The study was conducted in order to obtain the data with users of at least one Social Networking Site. We present a Brand perception scale measured as a combination of 5 dimensions: Affective perception, Functional perception, Reputation, Brand Experience and interaction through Social Media. The relevance of the research is based on the importance of the generation of innovative ways of being close to the consumer. Now, the product differentiation is based on how to give the information to the consumer, to make contact in a high level natural way: social life. So in this paper we would state that go over consumer social interactions are alternative marketing strategies in order to be close with the consumers. We confirmed the measurement scale proposed.
\end{abstract}

Keywords: Branding, Social Media, Experiential Marketing

\section{Introduction}

Over the past decades, academics and practitioners have been trying to explore and better understand how consumerbrand perception is formed and how brands could generate engagement with their consumers as advocates. Although brand perception measurement has been improved, there is no scale that considers the social interaction as a component of brand perception scale.

Nowadays, measurement of the impact of the digital world on the traditional marketing mix is critical to the success of the marketing planning, especially in the communication effort.

Digital evolution and especially social media have changed how consumers and marketers communicate. Peer communication through social media (SM), a new form of consumer socialization, has profound impacts on consumer decision making and thus marketing strategies (Vinerean, et al., 2013). Schultz and Peltier (2013) establish as future research directions the study of how social media is

Cite this Article as: Karla Barajas-Portas (2015)," The Impact of Consumer Interactions in Social Networking Sites on Brand Perception ", Journal of Internet and e-Business Studies, Vol. 2015 (2015), Article ID 197131, DOI: 10.5171/2015.197131 
an opportunity for marketers to generate brand engagement.

Based on the human natural condition as a social being, we have to take in account that socialization is a condition of identity, which defines the attitudes and behaviors and facilitates social integration into an environment of diversity and autonomy (Brakus, et al., 2009).

Social networks are digital communication platforms which empower the user to create content and share information through a public or a private profile. On the other hand, brands are considered as agents of social influence, so we are trying to determine the impact of the social media tools on the brand perception (Martí \& Muñoz, 2008).

Marketers are now able to reach consumers and interact with them using SM. Previous studies have found that consumers tend to trust more usergenerated messages, such as peer recommendations or consumer reviews, on SM than messages from traditional mass media (Chung \& Austria, 2010).

The usage of the variables from the traditional scale of brand perception lets a gap between the offline marketing mix and the online one. For that, we consider that it is mandatory to develop a scale for the brand perception that includes all the possible ways of impact. The aim of this paper is to prove the viability of the integration of the interaction between consumers and brands on social media networks.

We make a literature review considering 2 topics: Brand perception and social media marketing in order to blend both topics and prove the influence of the second one on brand perception. We consider several authors to select the best scale that could be adapted for our purpose and we test it.

The results explain that interaction among consumers and brands on SNS has an impact on brand perception. We used 6 items to estimate the interaction on SNS, but 2 of them have more reliability as components for the affective perception and reputation.

\section{Literature Review}

Brand perception measurement has become nowadays one of the most important topics for marketers and social media. According to Kotler, brands aim to build partnerships, evoke processes, fulfill promises of value, trigger emotions and build communities (Kotler, et al., 2010).

SM provides a virtual space for people to communicate through the internet, which also might be an important agent of consumer socialization. Consumer socialization theory predicts that communication among consumers affects their cognitive, affective and behavioral attitudes (Ward, 1974).

SM influences on consumers' life in many aspects. Their lives have changed tremendously about how they communicate with others, how, when and where they shop and their making decision process.

In recent years, SM or specifically Social networking sites (SNS) have increased in popularity. Facebook and twitter are the kings of this type of platforms, having the largest communities. It is important to mention that in the last couple of years; the fragmentation of SNS has been dramatic, introducing a multiple specialized platforms that allow people to interact with peers with similar interests. As an example, we can mention Instagram, Pinterest, Get Glue or Vine. This kind of SNS does not have the same number of members as Facebook or twitter, but they are centered on a specific preferences and habits. The segmentation characteristics of the specialized SNS are a great opportunity for marketers, improving the personal and adequate interaction between brands and consumers.

SNS enable users to present themselves, establish and maintain social connections with others, and articulate their own social networks (Ellison, et al., 2007). SM allows 
the creation and exchange of usergenerated content.

SM provides a new landscape for brand marketing communication, where consumers take more active role as marketers (prosumers), and brands are social currency (Chi, 2011). The advocates and prosumers transform the communications between brands and consumers, helping marketers to connect them in the context of SM. The objective is to engage consumers and the use of a natural human condition like socialization and interaction improves any approach between them. Digital word-of-mouth can have larger impact on consumers than traditional advertising or any other marketing communication activity, at least 8 consumers trust on other consumers more than on companies. The others' recommendations have a direct impact on the behavior of consumers as well as on consumers' perceptions of quality (Martí \& Muñoz, 2008).

According to Keller (2009), the marketing communications environment has changed tremendously and he says that brands have to change their way to communicate with consumers and to make the most with the new conditions of the brand communications as a bidirectional action. "To achieve intense, active loyalty relationships and brand resonance, marketers must incorporate consumers differently into their brand plan

ing. To better account for the different forces that now exist in the marketing environment and the role that they play in the formation of brand resonance, another framework, the brand resonance network, is helpful.

Table 1: Brand perception proposed scale

\section{Research Methods}

The present study aims to establish an extended brand perception scale including as a new component the interaction that occurs between the brand and consumers on the SNS.

Brand perception scale was developed adapting the previous research of the following authors: Keller (1993), Aaker (1994), Aaker (1996), Winchester \& Fletcher (2000), Fombrun et al (2000), Villarejo (2002), Sonnier \& Ainslie (2011), Brakus et al (2009). Brand perception is measured as a combination of 4 dimensions: Affective perception, Functional perception, Reputation and Brand Experience.

Based on brand perception scale, we propose a new extended model which provides relevant information of the evolution of brand perception, including the new concept of Interaction through Social Media. The items of the scale should focus on the impact of the 5 dimensions of the Brand Perception measurement. 
Table 1: Brand perception proposed scale

\begin{tabular}{|c|c|c|}
\hline Factor & Code & item \\
\hline \multirow{3}{*}{$\begin{array}{l}\text { Functional } \\
\text { perception }\end{array}$} & F1 & This Brand pay attention on my needs \\
\hline & F2 & The products of this brand are high quality \\
\hline & F3 & The product of this brand is useful \\
\hline \multirow{4}{*}{$\begin{array}{l}\text { Affective } \\
\text { perception }\end{array}$} & A1 & This brand induces feelings and sentiments \\
\hline & A2 & I have strong emotions to this brand \\
\hline & A3 & This brand is an emotional brand \\
\hline & A4 & This brand makes me feel good \\
\hline \multirow{3}{*}{ Reputation } & R1 & This brand has the best products \\
\hline & $\mathbf{R 2}$ & This brand is social responsible \\
\hline & R3 & I know the origin of the products of this brand \\
\hline \multirow{4}{*}{ Brand Experience } & E1 & $\begin{array}{l}\text { This brand makes a strong impression on my visual } \\
\text { sense or other senses }\end{array}$ \\
\hline & E2 & I find this brand interesting in a sensory way \\
\hline & E3 & This brand results in bodily experiences \\
\hline & E4 & This brand is not action oriented \\
\hline \multirow{6}{*}{ Interaction } & S1 & $\begin{array}{l}\text { I think the content shared by this brand on the } \\
\text { socialmedia networks is interesting }\end{array}$ \\
\hline & S2 & $\begin{array}{l}\text { I follow the brand pages in order to obtain recent } \\
\text { information of the brand/products }\end{array}$ \\
\hline & S3 & $\begin{array}{l}\text { I visit the brand page on social media networks } \\
\text { regulary }\end{array}$ \\
\hline & S4 & $\begin{array}{l}\text { I follow the brand pages to get in contact with other } \\
\text { people who have similar interests to me }\end{array}$ \\
\hline & S5 & $\begin{array}{l}\text { I follow the brand pages because of my attachment } \\
\text { to the brand }\end{array}$ \\
\hline & S6 & $\begin{array}{l}\text { I find the topics shared in the brand pages } \\
\text { remarkable }\end{array}$ \\
\hline
\end{tabular}

The survey consists of 36 questions, eight of them were demographic, 12 related to uses of SMN, the rest items were related to brand perception and interaction with brands. We use a seven-point Likert scale (1="completely disagree", and $7=$ "completely agree") for the 20 items provided in Table 1.

We conduct the study obtaining the data with real users of at least one Social Networking site. The information was collected from respondents via a digital survey between April and May 2014. We used the convenience sampling technique which implies a non-probability sampling. We ask 163 real users to answer the questionnaire. The sample was represented by undergraduate students of the Universidad Anahuac Mexico Norte,

$47 \%$ male and 53\% female. Respondents ranged in age from 19 to 24 . We found that all of them use at least Facebook, 89\% use also twitter and 2 people use 10 different SNS. $86 \%$ of the respondents use SNS several times a day, $67.3 \%$ use SNS once each day, $3.4 \%$ few times a week.

We ask SNS users if they interact with at least one brand in digital platforms. We 
ask them if they interact with their favorite brand and if they consume that brand. All the questions about interaction are according to the brand that the user designed as the favorite one. We are not researching about a brand or a category brand, we are trying to understand which is the bond and how does it impact brand perception.

\section{Research Results}

We conducted a factor analysis using varimax rotation. According to the factor analysis, we examined the five-factor solution considering items that had a loading greater than (.5). The Cronbach's alphas were adequate: Functional perception items (.73), Affective perception items (.68), Reputation items (.67), Brand Experience items (.78) and Interaction (SM) items (.76)

In order to taste the stability of the scale, we used structural equation modeling to conduct confirmatory factor analysis to determine if the measurement model fits the data. We analyzed a model that assumed that all items loaded on a single brand perception factor and a one-factor second-order model with 5 subdimensions, a one-factor second-order model with 4 sub-dimensions and a onefactor second-order model with 3 subdimensions.

The confirmatory factor analyses revealed that the best model was the one-factor second-order model with 5 sub-dimensions (Figure 2). The model fit is acceptable: The goodness-of.fit index (GFI) = .98; the comparative fit index $(\mathrm{CFI})=.98$; the root mean square error of approximation $($ RMSEA $)=.008$ and $X^{2}(26)=26.51$.

The initial evidence from the study reveals two items that originally were considered as part of the interaction construct fit better on affective perception (S5) and reputation perception (S6). 
IBIMA Publishing

Journal of Internet and e-Business Studies

http://www.ibimapublishing.com/journals/JIEBS/jiebs.html

Vol. 2015 (2015), Article ID 197131, 7 pages

DOI: $10.5171 / 2015.197131$

Table 2: Measurement Model Results

\begin{tabular}{|c|c|c|c|c|}
\hline Factor & Code & item & $\begin{array}{l}\text { Factor } \\
\text { Loading }\end{array}$ & $\begin{array}{c}\text { Reliability } \\
(\alpha)\end{array}$ \\
\hline \multirow{3}{*}{ Functional perception } & F1 & This Brand pay attention on my needs & 0.897 & \multirow{3}{*}{0.946} \\
\hline & F2 & The products of this brand are high quality & 0.875 & \\
\hline & F3 & The product of this brand is useful & 0.732 & \\
\hline \multirow{5}{*}{ Affective perception } & A1 & This brand induces feelings and sentiments & 0.912 & \multirow{5}{*}{0.912} \\
\hline & A2 & I have strong emotions to this brand & 0.908 & \\
\hline & A3 & This brand is an emotional brand & 0.821 & \\
\hline & A4 & This brand makes me feel good & 0.739 & \\
\hline & S5 & I follow the brand pages because of my attachment to the brand & 0.845 & \\
\hline \multirow{4}{*}{ Reputation } & R1 & This brand has the best products & 0.881 & \multirow{4}{*}{0.739} \\
\hline & R2 & This brand is social responsible & 0.632 & \\
\hline & R3 & I know the origin of the products of this brand & 0.528 & \\
\hline & S6 & I find the topics shared in the brand pages remarkable & 0.755 & \\
\hline \multirow{4}{*}{ Brand Experience } & E1 & $\begin{array}{l}\text { This brand makes a strong impression on my visual sense or other } \\
\text { senses }\end{array}$ & 0.886 & \multirow{4}{*}{0.847} \\
\hline & E2 & I find this brand interesting in a sensory way & 0.875 & \\
\hline & E3 & This brand results in bodily experiences & 0.845 & \\
\hline & E4 & This brand is not action oriented & 0.755 & \\
\hline \multirow{4}{*}{ Interaction } & s1 & $\begin{array}{l}\text { I think the content shared by this brand on the socialmedia networks } \\
\text { is interesting }\end{array}$ & 0.886 & \multirow{4}{*}{0.847} \\
\hline & S2 & $\begin{array}{l}\text { I follow the brand pages in order to obtain recent information of the } \\
\text { brand/products }\end{array}$ & 0.794 & \\
\hline & S3 & I visit the brand page on social media networks regulary & 0.743 & \\
\hline & S4 & $\begin{array}{l}\text { I follow the brand pages to get in contact with other people who } \\
\text { have similar interests to me }\end{array}$ & 0.839 & \\
\hline
\end{tabular}

Cite this Article as: Karla Barajas-Portas (2015)," The Impact of Consumer Interactions in Social Networking Sites on Brand Perception ", Journal of Internet and e-Business Studies, Vol. 2015 (2015), Article ID 197131, DOI: 10.5171/2015.197131 


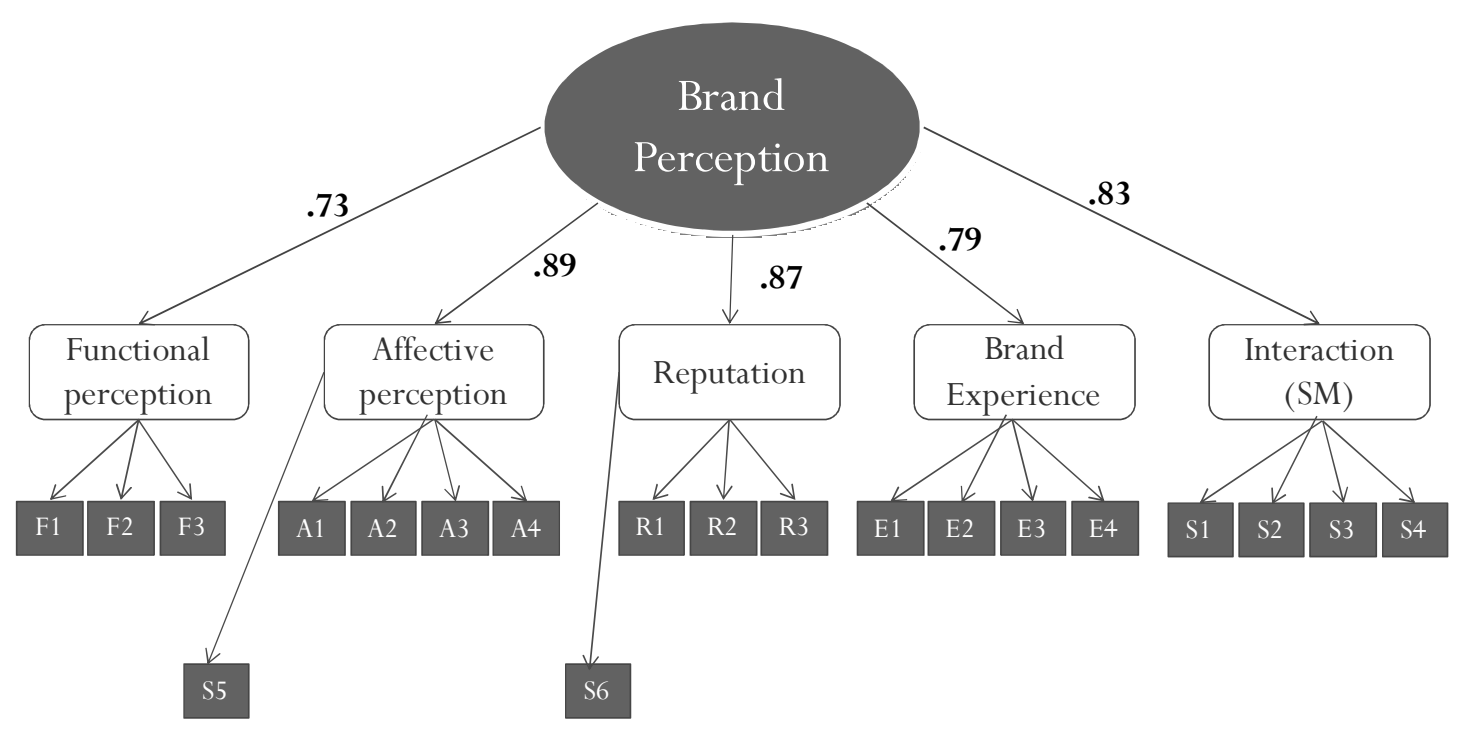

Figure 1: Brand perception extended model

\section{Conclusions}

The 20-item perceptions including functional, affective, reputation, experience and interaction, capture in a reliable and stable way five dimensions of Brand perception in accordance with the literature and Hypothesis established. The scale is short and easy to administer, and it is internally consistent and reliable. It is important to mention that interaction scale has been developed with the aim of being included in brand perception scale as a sub-dimension.

Results checked concerning measurement of interaction (SNS) leaving open research for extending the model factor exposed theory to a complete structural model to demonstrate the relationship or the influence of this factor measured on the brand perception.

The importance of this research is taking the first step for the measurement of Digital Interaction giving new marketing strategies for the theoretical and empirical support which has the importance of these factors for consumers. In this way, companies must pay more attention to their actions on Social Media and control agents that inherently exist in products and optimizing their use to improve your brand image actions and generate sustainable competitive advantage in time. The natural human processes as socialization and interaction are the first link in the production of emotions and remain on consumers' minds and hearts for longer than the images of traditional communication.

We select the originally suggested model as the most suitable, because it fits properly, and even though some of the items have loaded low factor, they were all significant. According to the theory and previous studies, it is necessary to maintain these variables, which provide theoretical and statistical model stability. The conceptual model was supported theoretically with measurement validity and reliability.

It is precise to emphasize that it has been considered at all times as a multidimensional construct, not as an isolated feature as often to be taken into account.

The principal limitation of the study is that the sample recruited consisted of college students, and although this kind of users represents an extended part of heavy users, it cannot extrapolate the results to the whole population. Despite this limitation, the study provides empirical evidence of the effects of social media marketing on brand perception. The results have implications for both social media 
marketing practices and research marketing.

For effective interactivity, marketers must pay attention to how they act or ignore the actions of people in the digital world. They have to participate in SNS and encourage and empower their consumers to get involved.

For future research, the new extended brand perception scale could be part of a structural path model in order to test their impact on purchase intention and/or on loyalty.

\section{References}

1. Aaker, D., (1994). Gestión del valor de la marca. Capitalizar el valor de la marca. Madrid: Díaz de Santos.

2. Aaker, D., (1996). 'Measuring Brand Equity across products and markets'. California Management Review, 38, 102120.

3. Brakus, J., Schmitt, B. and Zarantonello, L., (2009). 'Brand Experience:What is it? How is it measured? Does it affect loyalty?" '. Journal of Marketing, 52-68.

4. Chi, H.-H., (2011). 'Interactive Digital Advertising vs Virtual Brand Community: Exploratory study of user motivation and social media marketing responses in Taiwan'. Journal of Interactive Advertising, 12(1), 44-61.

5. Chung, C. and Austria, K., (2010). 'Social Media Gratification and Attitude towards Social Media Marketing Messages: A study of the effect of Social Media Marketing Messages on Online Shopping Value' s.l., 581-586.

6. Ellison, N. B., Stenfield, C. and Lampe, C., (2007). 'The benefits of Facebook 'Friends': Social Capital and College Students Use of Online Social Network Sites'. Journal of Computer-Mediated Communication, 12(4).

7. Fombrun, C., Gardberg, N. and Sever, J., (2000). 'The Reputation Quotient: A Multiple Stakeholder Measure of Corporate
Reputation'. The Journal of Brand Management, 241-255.

8. Keller, K., (1993). 'Conceptualizing, measuring, and managing customer-based brand equity'. Journal of Marketing, 57, 122.

9. Keller, K. L., (2009). 'Building strong brands in a modern marketing communications environment'. Journal of Marketing Communications, 15(2-3), 139155.

10.Kotler, P., Kartajaya, H. and Setiawan, I., (2010). Marketing 3.0. New Jersey: John Wiley \& Sons, Inc..

11.Martí, J. and Muñoz, P., (2008). Engagement Marketing. Madrid: Pearson Education.

12.Schultz, D. and Peltier, J., (2013). 'Social media's slippery slope: challenges, opportunities and future research directions'. Journal of research in interactive marketing, 7(2), 86-99.

13.Sonnier, G. and Ainslie, A., (2011). 'Estimating the value of Brand-Image Associations: The Role of General ans Specific Brand Image'. Journal of Marketing Research, XLVIII, 518-531.

14.Villarejo, A., (2002). La Medición del Valor de Marca en el Ámbito de la Gestión de Marketing. Madrid: Pirámide.

15.Vinerean, S., Cetina, J., Dumitrescu, L. and Tichindelean, M., (2013). 'The effects of social media marketing on online consumer behavior'. International Journal of Business and Management, pp. 66-79.

16.Ward, S., (1974). 'Consumer Socialization'. Journal of Consumer Research, pp. 1-14.

17.Winchester, M. and Fletcher, M., (2000). 'Calibrating your Brand Image Measurement'. Journal of Brand Management, 8(2), 99-110. 